\title{
Hybrid Formation in Mixtures of Hemoglobins and Isolated Hemoglobin Chains from Different Species
}

'Hybrid' hemoglobins, i.e. hemoglobins containing $\alpha$ and $\beta$ chains from different animal species, are known to form when the original hemoglobins are mixed under conditions in which they have a strong tendency to dissociate into monomeric subunits ${ }^{1,2}$.

Although there are indications that dissociation into single chains is finite but small even at neutral $\mathrm{pH}$ and low ionic strength ${ }^{3,4}$, mixtures of hemoglobins do not show any hybrid formation ${ }^{2,3}$. In the present work, mixtures of canine hemoglobin and isolated human hemoglobin chains were analyzed in order to establish whether they hybridize.

Material and methods. Human and canine hemoglobin were prepared with toluene from freshly drawn adult human and canine blood. The isolated hemoglobin chains (PMB chains) were prepared according to BuccI and Fronticelli ${ }^{5}$. The chains with free $\mathrm{SH}$ groups were obtained by emulsification with dodecanethiol (DE RENzo et al. ${ }^{8}$ ).

Canine hemoglobin and $\alpha^{\mathrm{SH}}$ or $\beta^{\mathrm{SH}}$ chains were mixed at a concentration of $3 \mathrm{mg} / \mathrm{ml}$ in $0.01 M$ phosphate buffer at $\mathrm{pH}$ 7. The mixtures were divided into 3 aliquots which were kept: one at room temperature, the second at $4^{\circ} \mathrm{C}$, and the third at $4{ }^{\circ} \mathrm{C}$ dialysing against distilled water. At the same time mixtures of human and canine hemoglobin were prepared under the same conditions. The hybridization of human and canine hemoglobin was followed according to ITANo and RoBINSON ${ }^{\mathbf{1}}$. The starch gel electrophoreses were carried out with the discontinuous buffer system according to POULIK ${ }^{7}$.

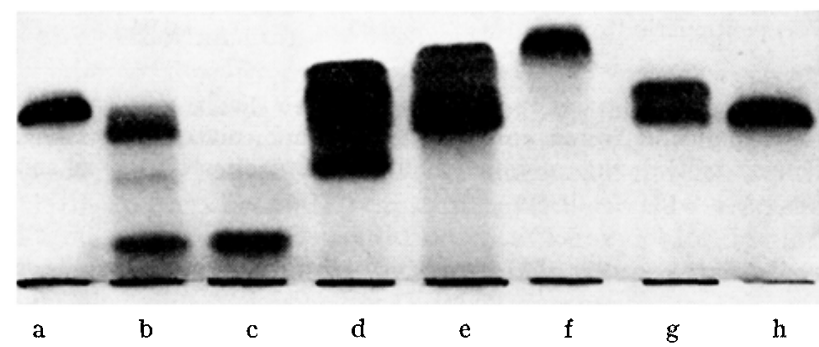

Fig. 1. Starch gel electrophoresis in the discontinuous buffer system according to Poulik. Stained with benzidine. Mixtures dialysed for 3 days against distilled water. (a) $\mathrm{HbA}$; (b) $\alpha \mathrm{SH}+$ canine $\mathrm{Hb}\left(4^{\circ} \mathrm{C}\right)$; (c) $\alpha \mathrm{SH}$; (d) $\mathrm{HbA}+$ canine $\mathrm{Hb}$ (hybridized); (e) $\beta \mathrm{SH}+$ canine $\mathrm{Hb}$ $\left(4^{\circ} \mathrm{C}\right)$; (f) $\beta \mathrm{SH}$; (g) $\mathrm{HbA}+$ canine $\mathrm{Hb}\left(4^{\circ} \mathrm{C}\right)$; (h) canine $\mathrm{Hb}$.

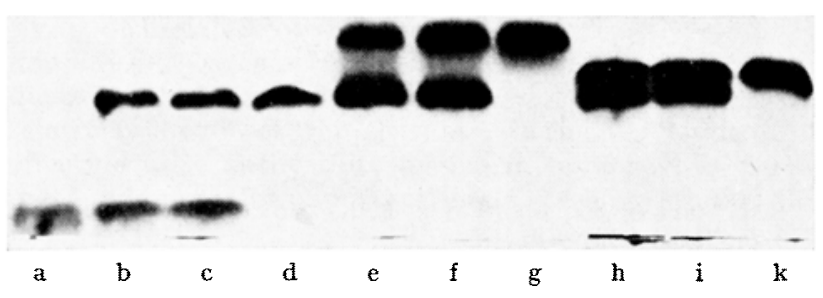

Fig. 2. Starch gel electrophoresis in the discontinuous buffer system according to Poulik. Stained with benzidine. Solutions in $0.01 \mathrm{M}$ phosphate 3 days after mixing. (a) $\alpha \mathrm{SH}$; (b) $\alpha \mathrm{SH}+$ canine $\mathrm{Hb}$ (room temperature); (c) $\alpha \mathrm{SH}+$ canine $\mathrm{Hb}\left(4^{\circ} \mathrm{C}\right)$; (d) canine $\mathrm{Hb}$; (e) $\beta \mathrm{SH}$ plus canine $\mathrm{Hb}$ (room temperature); (f) $\beta \mathrm{sH}+$ canine $\mathrm{Hb}\left(4^{\circ} \mathrm{C}\right)$; (g) $\beta \mathrm{SH}$; (h) $\mathrm{HbA}+$ canine $\mathrm{Hb}$ (room temperature); (i) $\mathrm{HbA}+$ canine $\mathrm{Hb}\left(4^{\circ} \mathrm{C}\right) ;(\mathrm{k}) \mathrm{HbA}$.
Results. The gel electrophoresis experiments of the mixtures of canine hemoglobin and human hemoglobin chains show that: (1) the mixtures of canine hemoglobin with $\alpha^{\mathrm{SH}}$ (Figure $1 \mathrm{~b}, \mathrm{c}, \mathrm{h}$ ) and $\beta^{\mathrm{SH}}$ (Figure 1e, f, h) dialysed for 3 days against distilled water at $4^{\circ} \mathrm{C}$ each show a new band with intermediate electrophoretic mobility apart from the original components. The new fractions obtained have the same mobility as the ones formed by hybridization of human and canine hemoglobin $^{1}$ (Figure 1d): in fact the hybrid between canine hemoglobin and $\beta^{\text {sH }}$ corresponds to the fast anodic hybrid (Figure 1e, d) that with $\alpha^{\mathrm{SH}}$ to the slow one (Figure 1b, d). In this last experiment the $\alpha^{\mathrm{SH}}$ chains were contaminated by a small amount of $\alpha^{\mathrm{PMB}}$ chains, which happen to have the same mobility as the slow hybrid. Human and canine hemoglobin in the same conditions do not show any hybrid formation (Figure $1 \mathrm{a}, \mathrm{g}, \mathrm{h}$ ). (2) The mixtures of canine hemoglobin with $\alpha^{\text {SH }}$ (Figure $2 \mathrm{a}, \mathrm{c}, \mathrm{d}$ ) and $\beta^{\mathrm{SH}}$ (Figure 2d, f, g) which have been kept for 3 days at $4^{\circ} \mathrm{C}$ in $0.01 M$ phosphate buffer show only the bands corresponding to the parent substances. The same solutions kept at room temperature show only a very weak band with intermediate mobility in the mixture of canine hemoglobin with $\beta^{\mathrm{SH}}$ chains (Figure 2e), but not with $\alpha^{\text {sH }}$ chains (Figure $2 b$ ). At room temperature, however, the instability of the solutions over a long period of time prevented an accurate analysis.

Discussion. The hybrid formation between canine hemoglobin and isolated human hemoglobin chains indicates, in agreement with the expectations, that dissociation of canine hemoglobin into chains occurs even at neutral $\mathrm{pH}$ and low ionic strength. The extent of hybrid formation is smaller in dilute phosphate buffer than in the absence of salts, which might indicate that dissociation into chains is increased in these conditions. The increased dissociation into isolated chains in the absence of salts might be related to the peculiar oxygen binding behaviour at very low ionic strength 4 .

Riassunto. Miscele di emoglobina canina e catene isolate di emoglobina umana, tenute a $\mathrm{pH}$ neutro e a bassa forza ionica, mostrano la formazione di molecole ibride. La formazione di ibrido in tampone fosfato diluito è minore che in assenza di sali.

\section{Carmela Ioppolo, Emilia Chiancone} and L. FORLANI

Institute of Biological Chemistry, University of Rome and C.N.R. Centre of Molecular Biology, Roma (Italy), 13 November 1967.
1 E. RoBinson and H. ITANo, Nature 188, 798 (1960).

2 E. Antonini, J. Wyman, E. Bucct, C. Fronticelli and A. Rossi Fanelli, J. molec. Biol. 4, 368 (1962).

3 A. Rossi Fanelli, E. Antonini and A. Caputo, Adv, Protein Chem. 19, 73 (1964).

4. A. Antonini, M. Brunori and S. Anderson, J. biol, Chem. in press.

\$ E. Bucci and C. Fronticelli, J. biol. Chem. 240, 551 (1965).

- E. De Renzo, C. Ioppolo, G. Amiconi, J. Wrman and E. AntoNINI, I. biol. Chem., in press.

7 M. D. PovLIK, Nature 180, 1477 (1957). 